\title{
A FORMAÇÃO DO ESTADO NA CONTEMPORANEIDADE A PARTIR DA REVOLUÇÃO RUSSA - UM SÉCULO DETERMINANTE DOS NOVOS RUMOS DA SOCIEDADE E DO DIREITO
}

\author{
THE FORMATION OF THE STATE IN CONTEMPORANEITY SINCE THE RUSSIAN \\ REVOLUTION - A DETERMINING CENTURY OF THE NEW RIGHTS OF SOCIETY \\ AND LAW
}

\begin{abstract}
Viviane Sellos Knoerr
Doutora em Direito do Estado pela Pontifícia Universidade Católica de São Paulo (2005).

Mestre em Direito das Relações Sociais pela Pontifícia Universidade Católica de São Paulo (1996). Graduada em Direito pela Universidade Federal do Espírito Santo (1991). É advogada. Professora e Coordenadora do Programa de Mestrado em Direito Empresarial e

Cidadania do Centro Universitário Curitiba ? UNICURITIBA. Realizou estágio PósDoutoral na Universidade de Coimbra (2015/2016). Tem experiência em:

Responsabilidade Social da Empresa. Dignidade da Pessoa Humana. Cidadania. Ética. Interpretação e Aplicação da Constituição. Tutela de Direitos Difusos e Coletivos.

E-mail: viviane@sellosknoerr.com.br
\end{abstract}

Fernando Gustavo Knoerr

Doutor em Direito do Estado pela Universidade Federal do Paraná (2002). Mestre em Direito do Estado pela Universidade Federal do Paraná (1998). Bacharel em Direito pela

Universidade Federal do Paraná (1993). Procurador Federal. Professor de Direito Administrativo da Escola da Magistratura do Paraná e da Fundação Escola do Ministério

Público do Paraná / FEMPAR. É Professor Permanente do Programa de Mestrado em

Direito Empresarial e Cidadania do UNICURITIBA. Realizou estágio Pós- Doutoral na Universidade de Coimbra, Portugal (2015-2016). Tem experiência em: Direito do Estado.

Crise da Administração e da Representação Política. Contratos Públicos. Cidadania. Integração e Globalização. E-mail: fernando@sellosknoerr.com.br

Recebido em: 30/09/2017

Aprovado em: 04/12/2017

Doi: $10.5585 /$ rdb.v18i7.789

RESUMO: Ao revisitar a história da Rússia no que tange o movimento revolucionário, o presente artigo objetiva traçar um paralelo com a formação de um Estado em contínua transformação e/ou revolução oriunda de convicções ideológicas, políticas e econômicas. Com breve retrospecto histórico, o artigo visita a formação do Estado (patrimonialista ou burocrático) também à luz de Max Weber. Trata-se, na sequência, da transição do Estado liberal ao Social com pressupostos de liberdades, direitos e garantias que superam a soberania a fim de outorgarlhe o dever legal de prestar serviços públicos. Por conseguinte, essa transformação repercute no direito e passa a ser protagonista na construção de um novo modelo de Estado. Para o desenvolvimento deste artigo, a historiografia retratada se vale da metodologia bibliográfica, a qual contribui para a compreensão da formação do Estado e direito contemporâneos.

Palavras-Chave: Formação do Estado, Revolução Russa, Nova Sociedade, Novo Direito, Estado Social. 


\begin{abstract}
In revisiting the history of Russia in relation to the revolutionary movement, this article aims to draw a parallel with the formation of a state in continuous transformation and / or revolution originating from ideological, political and economic convictions. With a brief historical retrospective, the article visits the formation of the state (patrimonialist or bureaucratic) also in the light of Max Weber. This is followed by the transition from the Liberal to the Social State with the assumptions of freedoms, rights and guarantees that surpass sovereignty in order to grant it the legal duty to provide public services. Consequently, this transformation has repercussions on the law and becomes a protagonist in the construction of a new state model. For the development of this article, the historiography portrayed relies on the bibliographical methodology, which contributes to the understanding of the formation of the contemporary state and law.
\end{abstract}

Keywords: State Formation, Russian Revolution, New Society, New Law, Social State.

SUMÁRIO: Introdução; 1. A revolução russa; 2. Formação do estado social em max weber; 3. O estado social; Conclusão; Referência bibliografia.

\title{
INTRODUÇÃO
}

Pela via historiográfica o artigo conduz o leitor à compreensão do Estado Contemporâneo, assim como de um novo direito capaz de atender, tanto o exercício da soberania estatal, e, por conseguinte, de direitos individuais e meta-individuais tutelados pela nova ordem jurídica oriunda de um Estado advindo de transformações e/ou revoluções influenciadoras de sua formação e atuação social.

Revisitar a história significa a busca pela origem daquilo que se pesquisa, assim, pode dizer que o referencial histórico no primeiro capítulo do presente artigo se parte da Revolução Russa com início em 1917, com a queda do czarismo instaurando a "ditadura do proletariado", surgindo, assim, a fase socialista. Naquele contexto histórico verifica-se um cenário de conflito interno decorrente de convicções ideológicas, políticas e econômicas em que o governo era disputado pela burguesia e pelos socialistas do Partido Operário Social-Democrata Russo (POSDR), divididos entre os bolcheviques e os mencheviques. Com a crise instaurada no sistema político russo, a decadência de seu império socialista começa a se evidenciar na década de 1970. Já na década de mil novecentos e oitenta, o presidente Mikhail Gorbatchov deu início à reforma política, econômica e social advindo de momentos pretéritos que levaram à transformação vivenciada atualmente. Assim, o capítulo primeiro tangencia o retrospecto histórico e seus acontecimentos para a compreensão da Estado Russo contemporâneo.

Por outro, o capítulo segundo, à luz de Max Weber, traz a formação do Estado Social, originado, segundo ele, no momento em que a situação econômica da Alemanha pós a primeira guerra mundial impõe mudanças no sistema político que se fizera necessário alterar o Estado Liberal para um estado preocupado com o bem-estar dos indivíduos. Começa a surgir o modelo de Estado Social, ou burocrático. Como deputado, Weber for o relator da Constituição de Weimar a qual visava o welfare state, ou estado do bem-estar social.

Da análise de Weber, se extrai o conceito de relação social, a qual distinguiu os modelos de ação social racionalmente orientada, ação social idealmente orientada, ação tradicional e ação afetiva, sendo essas as formas de agir e como causa do comportamento dos indivíduos, e, por conseguinte orienta o conceito de relação social, resultante da interação das ações sociais. Essa contribuição quanto ao conceito de relação social weberiana passa a ter importância para a ciência política ao tratar do poder, classificada como sendo "poder é relação", configurada entre mandatário e mandante, desde que a ordem emanada seja cumprida, assim estaria evidenciado o poder pleno. 
Nesse viés weberiano, apresenta-se a distinção entre dominação e poder, ladeando a temática quanto a legitimidade de quem age em detrimento de outrem. Assim, Weber ainda classifica formas de Estado, tendo por base os tipos ideais de legitimidade. Em sua compreensão, o Estado patrimonialista encontra lugar na legitimidade tradicional e na carismática e o Estado burocrático é amparado na legitimidade racional legal, sendo o âmbito pessoal do governante, totalmente separado do espaço público. Neste diapasão, o segundo capítulo se encerra com a análise da contribuição weberiana na formação do Estado social, decorrente da observância da realidade social que estava inserido, sendo, segundo o autor, necessária a mudança de uma ideologia política liberal para a social.

Por fim, o capítulo terceiro trata especificamente do Estado Social, sendo caracterizado pela concepção ideológica, mas sobretudo por questões econômicas, devido à revolução que se operou nos meios de produção. Para maior compreensão, faz-se necessária a revisita histórica ao Século XVIII, a chamada primeira revolução industrial, baseada no emprego da máquina a vapor e, consequentemente, no século XIX, a segunda revolução industrial, caracterizada pelo emprego da energia elétrica.

Perpassa, portanto, a história da sociedade contemporânea pelas transformações de políticas econômicas, por conseguinte, sociais, guiadas por convicções ideológicas formadas à partir da observância da realidade, tanto pela forma que o capitalismo se sobrepunha ao interesse social, quanto pela incapacidade do estado promover políticas públicas sem o próprio capital.

Assim, Estado e capitalismo unem e/ou medem forças para, em última análise, atender o bem comum. Dessa forma, o Estado passa a auxiliar o capitalista no que tange a prestação de serviços de base à classe proletária, chamados serviços públicos, tais como saúde, educação e previdência, dando origem aos serviços públicos.

Por fim, a temática tangencia a noção de essencialidade dos serviços públicos. Essenciais porque garantidores de um minimun necessário à preservação do status dignitatis do homem.

Com a necessidade de tutela dos indivíduos e da coletividade, disciplinados como direitos individuais de primeira e segunda gerações ou dimensões, em atenção à nova realidade social, eclode um novo ramo do Direito, o Administrativo, disciplinando a relação jurídica estabelecida entre o indivíduo e o Estado - Administração Pública, a partir da prestação de serviços públicos.

A partir deste novo modelo de Estado, o Social, o poder público passa a ter a obrigação de prestar serviços e não apenas a de exercer a soberania, de maneira que, uma vez transformada a sociedade, necessário que a ordem jurídica a persiga e alcance, ampliando seu campo de atuação e por vezes ultrapassando sua esfera de competência originária para atipicamente, suprir ou complementar, além do mero fazer cumprir as típicas obrigações legislativas e/ou executivas de criar, implementar e fiscalizar políticas públicas que atendam ao novo direito e ao Estado Social.

\section{A REVOLUÇÃO RUSSA}

O movimento revolucionário na Rússia teve início em 1917, com a queda do czarismo, e terminou com o estabelecimento da União das Repúblicas Socialistas Soviéticas (URSS), o primeiro país socialista do mundo, em 1922. Começou em 27 de fevereiro de 1917, pelo calendário russo e em 12 de março, pelo ocidental. Com a Revolução de Fevereiro, forçou-se a abdicação do czar. Em 25 de outubro, sempre pelo calendário russo, instaurou-se a "ditadura do proletariado", surgindo, assim, a fase socialista.

A Rússia, anterior à revolução, abrigava vários povos, etnias e culturas. Seu território era propriedade da nobreza. A população rural representava $80 \%$ dos habitantes. O avanço da industrialização fez crescer o número de proletários e as dificuldades econômicas e políticas 
estimularam ideias revolucionárias contra o regime czarista. Os gastos com a I Guerra Mundial diminuíram investimentos e elevaram preços, aumentando os conflitos internos que foram reprimidos violentamente. A fome chegou às cidades e a insatisfação passou a alcançar seu ápice em fevereiro de 1917. O Exército negou-se a marchar contra o povo e, no dia 27, pelo calendário russo, o czar Nicolau II abdicou o trono.

O governo é disputado pela burguesia, por meio do Comitê Provisório da Duma (espécie de Parlamento) e pelos socialistas do Partido Operário Social-Democrata Russo (POSDR), divididos entre os bolcheviques, que defendiam a revolução imediata e os mencheviques que, mais moderados, buscavam a revolução gradual, mediante reformas.

Os socialistas organizaram operários, soldados e camponeses em conselhos, chamados de soviets, que se reuniam nacionalmente no Congresso dos Soviets de Operários, Soldados e Camponeses. Por fim, instalou-se um governo provisório composto de ministros liberais e do socialista moderado Aleksandr Kérenski (1881-1970). Mas a crise interna prosseguiu, com a insistência por parte do governo em seguir na guerra. Cresceu a liderança de Lênin, o maior representante dos bolcheviques ${ }^{1}$, defendendo a saída da guerra, o fortalecimento dos sovietes e o confisco das grandes propriedades rurais para distribuí-las aos camponeses. A influência dos soviets nas fábricas e na Marinha aumentou. Os bolcheviques ganharam força, levantando como palavra de ordem "Pão, Terra e Trabalho". O governo reprimiu manifestações e perseguiu os bolcheviques, forçando Lênin a asilar-se na Finlândia. O fracasso na guerra provoca mudanças no governo, que passa de liberal a socialista moderado.

Em setembro, Leon Trótski (nome real Lev Davídovitch Bronstein), presidente do soviet de Petrogrado, criou o Exército Vermelho. Lênin voltou clandestinamente para o país e convenceu o comando bolchevique a partir para a revolução, defendendo que o poder passe aos soviets. A resistência de Kérenski em Moscou é vencida em 25/10/1917 (7 de novembro, pelo calendário ocidental). Os bolcheviques tomam o poder em 7/11/1917 e instituem o Conselho dos Comissários do Povo, presidido por Lênin. Trótski assume o Comissariado das Relações Exteriores e Josef Stálin, o das Nacionalidades. Os bolcheviques iniciaram a mudança do sistema político e econômico, concedendo aos camponeses o direito exclusivo de exploração das terras. Transferem o controle das fábricas aos operários, expropriam as indústrias e nacionalizam os bancos. Moscou passa a ser a capital do país, em substituição a Petrogrado. Em março de 1918, o governo assina paz em separado com a Alemanha, aceitando entregar a Polônia, a Ucrânia e a Finlândia. Sofre, no entanto, reação armada de ampla frente que reuniu capitalistas e mencheviques. Os contrarrevolucionários, chamados Brancos, recebem ajuda do Reino Unido, da França, do Japão e, mais tarde, da Polônia.

A Revolução consolidou-se na ocasião em que Trótski organizou o Exército Vermelho, responsável pela derrota dos contrarrevolucionários e das forças externas.

A vitória bolchevique instalou o terror, com o fuzilamento de milhares de pessoas, incluindo o czar e sua família. O governo passou a adotar medidas para reduzir a fome e

\footnotetext{
${ }^{1}$ Vladímir Ilitch Uliánov, vulgo Lênin ou Lenine. Revolucionário russo (1870-1924). Nascido em Sibirsk, atual Ulianovsk. Em 1891 formou-se em direito e, dois anos depois, mudou-se para São Petersburgo, onde adota idéias marxistas, dedicando-se à propaganda do comunismo nos bairros proletários. Em 1895 é preso e deportado para a Sibéria. Cumprida a pena, parte com a esposa para a Suíça em 1900, onde lança o jornal Iskra (A Centelha), sob o pseudônimo Lênin. Em 1902 funda no exterior o Partido Operário Social-Democrata Russo (POSDR), que logo se divide em duas facções: os bolcheviques, liderados por ele próprio, que defendem a revolução imediata e os mencheviques, favoráveis a uma revolução gradual, mediante reformas. Quando o czar Nicolau II abdicou, Lênin retornou ao país e liderou a oposição ao governo do socialista moderado Aleksandr Kerenski, até tomar o poder, em setembro. Dá aos camponeses o direito de explorar a terra, transfere o controle das fábricas aos operários e nacionaliza os bancos. Em 1921 instituiu a Nova Política Econômica (NEP), permitindo a criação de empresas privadas sob a supervisão do Estado. Em 1922 formou a União Soviética. Em 1923 sofreu um derrame que o deixa paralítico. Morreu no ano seguinte. Ele deixou evidente sua admiração por Marx, embora fosse crítico de alguns pontos de seu materialismo histórico. Sem Lênin, desencadeou-se uma luta pelo poder entre Trótski e Josef Stálin. Este saiu-se vencedor.
}

Revista de Direito Brasileira | São Paulo, SP | v. 18 | n. 7 | p. 363 - 373 | Set./Dez. 2017 
modernizar o país. Em 1921, com a revolução consolidada, Lênin implantou a NEP - Nova Política Econômica - um misto de socialismo e capitalismo, que tinha o objetivo precípuo de vencer o impasse econômico. Os bolcheviques permitiram a criação de empresas privadas e de um comércio em pequena escala, sob a supervisão do Estado; também autorizou empréstimos externos. A formação da URSS, em 1922, tentou manter unidos diversos territórios do antigo Império Russo que pouco têm em comum. A morte de Lênin, em 1924, provocou a luta pelo poder entre Trótski e Stálin, cada um com concepções diferentes de revolução. Trótski defendia a revolução mundial e permanente, enquanto Stálin pretendia implantar o socialismo apenas na URSS.

Por influência de Stálin, Trótski foi expulso do partido em 1927 e deportado em 1929. Passa por vários países até chegar ao México, em 1937, onde é assassinado três anos depois, por ordem de Stálin. Entre seus livros estão Tarefas Políticas (1904) e Entre o Imperialismo e a Revolução de 1922.

A decadência do Império socialista russo já começou a dar mostras na década de 70, identificada pela grave crise em seu sistema político, devido ao crescimento dos movimentos nacionalistas, e pela dificuldade econômica. Em 1985, o presidente Mikhail Gorbatchov deu início à reforma política, econômica e social (Perestroika). A queda do Muro de Berlim marcou o começo da extinção do regime comunista no Leste Europeu e provocou um conflito generalizado nos partidos comunistas, que, em sua maioria, abdicam de nome, programa e ideologia ${ }^{2}$.

Em 1991, a URSS desintegra-se e as ex-repúblicas soviéticas formam a Comunidade dos Estados Independentes (CEI). Sobrevivem, contudo, os governos comunistas da Coréia do Norte, do Vietnã, de Cuba e da China. Com exceção do primeiro, que ainda é um regime bastante fechado, os demais países já adotam algumas medidas econômicas de mercado aberto.

\section{FORMAÇÃO DO ESTADO SOCIAL EM MAX WEBER}

Sociólogo e economista alemão. Teórico das ciências sociais, escreveu o estudo denominado A Ética Protestante e o Espírito do Capitalismo. Nascido em Erfurt, fillho de um deputado liberal da Câmara Prussiana e rico industrial da área têxtil, estudou Direito em Heidelberg e economia em Berlim. Começou a lecionar economia na Universidade de Freiburg em 1893. Afastou-se três anos depois em virtude de um sério colapso nervoso. Voltando a lecionar em 1917, por breve período, pois recorrentes crises nervosas abalaram sua saúde levando-o a deixar a cátedra. A herança paterna lhe permite manter-se e escrever livros no decorrer da vida. Na sua obra mais célebre, A Ética Protestante e o Espírito do Capitalismo, de 1905, analisa a religião calvinista como alicerce fundamental para o desenvolvimento do capitalismo, tendo exercido profunda influência sobre a sociologia do século XX.

Weber também escreveu Estudos Reunidos sobre a Sociologia da Religião (1922) e História Econômica Geral (1923), entre outros trabalhos que analisam o papel das ideias filosóficas e religiosas no desenvolvimento econômico das sociedades. A teorização de Weber surge no momento em que a situação econômica da Alemanha logo após a $1^{\text {a }}$ guerra impõe

\footnotetext{
${ }^{2}$ É perceptível que os acontecimentos na história do socialismo seguem o rumo: $1^{\text {o: }}$ o socialismo utópico; $2^{\text {o: }}$ o marxismo ou socialismo científico e $3^{\circ}$ : o socialismo concreto (na Rússia, o primeiro país socialista do mundo). Outros conceitos importantes para entender o desenvolvimento do socialismo e suas nuanças partidárias são: $1^{\mathrm{a}}$ INTERNACIONAL SOCIALISTA: originou-se de um congresso internacional de socialistas em Berlim, em 1864. Marx participou deste encontro de líderes sindicais, onde foi apresentado o Manifesto Comunista. O evento deu nome aos próximos encontros; $2^{\mathrm{a}}$ INTERNACIONAL SOCIALISTA: discute as ideias vigentes até esse encontro. As ideias deste encontro prevalecem no período 1893-1910. Destaca-se Rosa de Luxemburgo que dizia: a revolução não cai do céu, é necessário fazê-la ganhar as ruas. Rosa morre num atentado a bomba; $3^{\mathrm{a}}$ INTERNACIONAL SOCIALISTA: após 1910, já inspirados no modelo concreto de Lênin, alguns socialistas debatem que se o que acontecia na Rússia (totalitarismo, massacres, fome) era o socialismo, ele jamais deveria ter sido implantado.
} 
mudanças no sistema político. A Alemanha perdera a guerra e era necessário alterar o Estado Liberal, que buscava resguardar a liberdade individual, transitando para um modelo de estado preocupado com o bem-estar dos indivíduos, com o fornecimento de um conjunto mínimo de serviços capazes de constituir o ponto inicial, um prius, para o pleno desenvolvimento. Começa a surgir o modelo de Estado Social, ou burocrático.

Reunida a assembleia constituinte em Weimar, Weber participou como deputado, tendo sido relator da Constituição de Weimar (cidade em que se reunia a Assembleia Constituinte) caracterizada como a primeira Constituição social da Europa, promulgada em 1919. ${ }^{3}$

Ação é toda conduta humana dotada de sentido e, especificamente, ação social é o motivo pelo qual alguém age de determinada maneira na vida social. Só quem pratica a ação é que tem condições de valorá-la, enquadrando-a em quatro imperativos: racional, ideal, tradicional e afetivo.

$\checkmark$ Ação social racionalmente orientada: a ação é destinada a atender um desejo pessoal, as aspirações do indivíduo. Cabe apenas ao autor da ação escolher os meios para atingir seus objetivos, por isso é considerada racional. É própria da ação a que se refere David Hume, colocando a razão como instrumento do interesse, destinado a definir o melhor caminho para atendê-lo.

$\checkmark$ Ação social idealmente orientada: neste caso a ação é conduzida por um sentimento altruísta, de preocupação com o próximo. O indivíduo dá valor ao que está fazendo, buscado atender o interesse de terceiros, outros (do latim: alter $=$ outro).

$\checkmark$ Ação tradicional: a ação é definida pela tradição, pelo hábito e, de tão repetida, insere-se na realidade como costume.

$\checkmark$ Ação afetiva: é destituída de caráter racional. A conduta é guiada por um impulso imediato.

Essas quatro formas de agir, postas como causa do comportamento dos indivíduos, de acordo com o pensamento weberiano, conduzem ao conceito de relação social, resultante da interação das ações sociais. Um indivíduo age e outro atua em reação, reage. Para que haja relação social não é necessário, contudo, que as ações sociais envolvidas estejam enquadradas na mesma qualificação. É assim possível estabelecer relação social entre uma ação idealmente orientada e outra afetiva; entre uma racionalmente orientada e uma tradicional.

Para a ciência política o conceito de relação social passa a interessar a partir da conclusão weberiana segundo a qual "poder é relação", estabelecida entre quem emite a ordem e quem a obedece. Não tem poder quem se limita a proferir a ordem. Tem-no efetivamente quem emite a ordem e consegue ser obedecido.

Weber distingue "dominação" (herschaft) e "poder" (gewalt). Enquanto a primeira significa toda probabilidade de impor a própria vontade numa relação social, o poder reflete a probabilidade de encontrar obediência a uma ordem de determinado conteúdo ${ }^{4}$.

O poder nunca é unilateral, pois quem dá uma ordem e consegue obter um certo grau de obediência/colaboração demonstra legitimidade de exercício do poder. Logo, a legitimidade é o reconhecimento do poder, aferido pelo grau de resposta positiva, de obediência à ordem dada. Quanto maior o grau de obediência, maior é a legitimidade do governante. Para isso, é necessário

\footnotetext{
${ }^{3}$ A primeira Constituição fundada no modelo de welfare state é a do México, promulgada em 1915.

${ }^{4}$ De relação aos regimes políticos, foi o francês Talleyrand um dos maiores estudiosos. Para ele: “(...) um governo legítimo, seja monárquico ou republicano, hereditário ou eletivo, aristocrático ou democrático, é sempre aquele cuja existência, forma e modo de ação estão consolidados e consagrados por uma longa sucessão de anos. [...] A legitimidade da potência soberana resulta do antigo estado de posse, assim como sucede, para os particulares, com a legitimidade do direito de propriedade." In CRUZ, André Luiz Vinhas. A legitimidade do poder de reforma constitucional. Publicada em Juris Síntese $n^{\circ} 50$ - NOV/DEZ de 2004.
} 
a quem obedece, ser dotado da liberdade de obedecer espontaneamente ao comando dado, sendo, portanto fundamental, como antes frisado, resguardar ao autor da ação a prerrogativa de enquadrá-la em uma das quatro qualificações separadas por Weber.

As formas de dominação, por sua vez, são classificadas por Weber em tipos ideais de legitimidade, os quais são os modelos teóricos, standarts de compreensão da realidade que não existem de forma pura. São utilizados para que a ciência, coerente por definição, consiga explicar a realidade incoerente, desencontrada e caótica. Tipos ideais, portanto, são apenas pontos de partida, criados e mantidos artificialmente para permitir explicar a realidade cientificamente. Weber separa três tipos ideais de legitimidade:

- Legitimidade tradicional: é baseada numa ação tradicional. Quem exerce o poder é obedecido em razão da tradição segundo a qual o governo passa de pai para filho dentro da mesma dinastia. Os súditos acostumam-se a reconhecer um Rei e a transmissão hereditária de poder, pois essa prática, de tão repetida, torna-se parte da tradição histórica dos próprios governados. Alguns escritores brasileiros de influência weberiana ${ }^{5}$ afirmam que o coronelismo no Brasil também é um poder legitimado pela tradição.

- Legitimidade carismática: é o reconhecimento do poder a alguém que se destaca do todo social por características que o fazem discrepante do padrão comum, marcado por afeição ou carisma - seja um herói ou ídolo - sem qualquer base racional. O carisma não considera a razão, apenas a afeição.

- Racional legal: é o modelo que reconhece o poder a alguém que foi escolhido através da razão estampada em lei. É racionalmente orientada porque o governante é escolhido de acordo com suas condições de atender o interesse pessoal e egoístico de cada um dos governados.

Essa sequência (tradicional, carismático e racional legal) dos tipos ideais conduz à conclusão de que, ao longo dessas formas de legitimação foi transparecendo um gradativo desencantamento com o mundo, pois toda a magia que cercava a figura quase divina do monarca ou até mesmo a sedução despertada pelo líder carismático foi ao longo do tempo perdendo espaço para as escolhas guiadas pela razão. Weber considera que as ações humanas, atingindo o $3^{\text {o }}$ estágio dos tipos ideais de racionalidade, ou seja, o grau de plena racionalidade, alcançarão a previsibilidade de todas as ações dos governantes, pois estes deverão agir estritamente de acordo com o que está estipulado na lei. Apenas assim o governo será legitimado.

Weber ainda classifica as formas de Estado tendo por base os tipos ideais de legitimidade, como patrimonialista e burocrático. O Estado patrimonialista encontra lugar na legitimidade tradicional e na carismática, caracterizado pela ausência de divisão entre a esfera pessoal do governante e o patrimônio público. O governante administra o Estado como se administrasse sua própria casa. Tudo no Estado lhe pertence. Já o Estado burocrático é amparado na legitimidade racional legal, sendo o âmbito pessoal do governante totalmente separado do espaço público. O Estado burocrático não é governado pela vontade pessoal do governante, mas pelo que determina a lei.

Ressalte-se, assim, que com a consolidação do modelo de Estado Social, o poder público tem agora a obrigação de prestar serviços públicos e não apenas a de exercer a soberania, o que a partir de Weber pode se compreender como a essência do Estado Democrático de Direito.

\section{O ESTADO SOCIAL}

O Estado social não teve origem apenas em concepções ideológicas, mas derivou em muito maior grau de contingências econômicas, devido à revolução que se operou nos meios de produção. A história registra no Século XVIII a chamada $1^{a}$ revolução industrial, baseada no

\footnotetext{
${ }^{5}$ LEAL, Victor Nunes. Coronelismo, enxada e voto. 3. ed. $1^{\text {a }}$ reimpressão. Nova Fronteira, 1997; FAORO, Raymundo. Os donos do poder. Ed. Folha de São Paulo, 2000.
}

Revista de Direito Brasileira | São Paulo, SP | v. 18 | n. 7 | p. 363 - 373 |Set./Dez. 2017 
emprego da máquina a vapor e, no século XIX, a $2^{\text {a }}$ revolução industrial, caracterizada pelo emprego da energia elétrica.

A primeira grande crise do capitalismo ocorreu devido à produção insuficiente, que não conseguiu suprir a demanda de bens. Faltava mão de obra, pois as guerras, as pestes no continente europeu acabaram com grande parte dos homens que operavam as pesadas máquinas a vapor e extraiam carvão das minas. O trabalho passou a ser imposto a mulheres e crianças, em condições desumanas. A mortalidade infantil alcançou índices alarmantes. Diante desse quadro crítico, o capitalismo (modelo econômico burguês) pede ajuda ao Estado (produto por excelência da criação política burguesa), com o forte argumento de que um não existe sem o outro.

O capitalismo é o modelo econômico burguês por excelência e o Estado é o principal produto da teoria política burguesa. Não há Estado sem capitalismo e não há capitalismo sem Estado. Se o capitalismo sucumbir à crise e deixar de existir, o mesmo ocorrerá com o Estado.

O Estado passa a auxiliar o capitalista, não mediante o repasse direto de recursos, mesmo porque esta técnica criaria um sistema de rápida exaustão econômica. Para sustentar e incrementar a força de trabalho, o Estado começou a prestar serviços de base à classe proletária, chamados serviços públicos, tais como saúde (no padrão mínimo suficiente para que ele continue trabalhando), educação (para aprender o indispensável na operar das máquinas), habitação (de preferência próxima ao local de trabalho) e previdência (lastreando a esperança de que o trabalhador possa algum dia viver sem trabalhar).

Nascem os serviços públicos.

Surge o Estado Social como um prestador de serviços que foi-se agigantando ao longo do tempo, fazendo a dignidade humana depender da prestação e do acesso aos serviços públicos. Sedimenta-se nesse contexto a noção de essencialidade dos serviços públicos, essenciais porque garantidores de um minimun necessário à preservação do status dignitatis do homem.

Como leciona Vital Moreira, "A idéia de dignidade humana é tão antiga quanto a história da humanidade e existe de variadas formas, em todas as culturas e religiões. Por exemplo, o importante valor atribuído ao ser humano pode ser encontrado na filosofia africana de ubuntu ou na proteção de estrangeiros no Islã. A 'regra de outo', segundo a qual devemos tratar os outros como gostaríamos de ser tratados existe em todas as grandes religiões. $O$ mesmo vale para a responsabilidade da sociedade de cuidar dos seus pobres e para as noções fundamentais de justiça social. Contudo, a idéia de ' direitos humanos' é o resultado do pensamento filosófico dos tempos modernos, com fundamento na filosofia do racionalismo e do iluminismo, no liberalismo e na democracia, e também no socialismo."6

Com o gradativo acréscimo na prestação de serviços públicos, nasce dentro da estrutura do Estado um segundo setor, a par do Governo: a Administração Pública.

Desde a origem do modelo liberal, o Estado era uma figura unicamente política, concentrando sua função no papel governamental do exercício da soberania e, por essa razão, a relação travada entre o indíviduo e o Estado-Governo centrava-se no jogo de forças próprio da relação política. Era uma relação estritamente política, autorizando caracterizar o Governo como a parte do Estado com a qual o indivíduo mantém relação política, reunindo institutos como o voto, as eleições, os partidos políticos, cartilhas ideológicas e mandato.

Setorizada a estrutura interna do Estado com o surgimento da Administração Pública, inaugura-se também uma nova forma de relação entre o individuo e o Estado, pois a consolidação do modelo de Estado social fortalece a concepção de que o indivíduo, impessoalmente considerado cidadão, tem direito de receber o serviço, de ser dele usuário, enquanto o EstadoAdministração Pública tem o dever de prestá-lo.

\footnotetext{
${ }^{6}$ MOREIRA, Vital. Compreender os direitos humanos. Manual de educação para os direitos humanos. Coimbra Editora. $1^{\text {a }}$ edição. Coimbra. 2014. p. 51.
}

Revista de Direito Brasileira | São Paulo, SP | v. 18 | n. 7 | p. 363 - 373 | Set./Dez. 2017 
Articular-se assim entre a Administração Pública e o indivíduo uma relação que não é mais política, pois não se pauta na polarização de poder e sujeição. Cria-se uma relação de direito e dever, com feição obrigacional, nitidamente jurídica.

Surge o Direito Administrativo, disciplinando esta relação (jurídica) estabelecida entre o indivíduo e o Estado-Administração Pública a partir da prestação de serviços públicos.

No Estado liberal o poder público estava fortemente limitado pela lei. Vigia a concepção, própria da formulação tradicional da legalidade, de que o Estado somente pode fazer o que a lei expressamente prevê e, de outro lado, o indivíduo tem a liberdade de fazer tudo que a lei não proíbe. A liberdade individual conceitua-se de forma negativa (liberdade negativa), pois decorre da falta de vedação legal e se destina a tutelar os direitos individuais contra possíveis abusos por parte do poder público.

No modelo político liberal, o estado atuava ilegalmente quando extrapolava o limite da lei, é dizer: quando abusava.

No modelo de estado social o indivíduo passa a titularizar direitos (à saúde, à educação, etc.) cuja satisfação depende da movimentação da estrutura do Estado. Nesse contexto, inaugurase uma nova formulação do princípio da legalidade, mais aberta, admitindo até mesmo que o Estado aja sem expressa autorização legal. Está habilitado a atuar no vazio, na lacuna da lei, desde que não prejudique o particular.

Ressalte-se que no modelo político social, o Estado age ilegalmente quando abusa, mas também quando se omite diante do dever legal de prestar o serviço público, enquanto no modelo liberal o indivíduo exerce direitos contra o poder público, no social os exerce através do poder público, da estrutura criada e custeada para prestar serviços públicos, chamada Administração Pública.

Observando-se as duas primeiras dimensões dos Direitos Humanos, verificam-se as peculiaridades da evolução jurídica pelas demandas sociais, pois, os Direitos individuais de $1^{a}$ geração, próprios do Estado Liberal, forçam o poder público a se manter dentro do seu espaço, centrando na linha da lei o jogo de forças estabelecido, de um lado, entre a tendência de abuso do poder público e, de outro, a resistência oferecida pelo indivíduo para tutelar sua liberdade, e já os Direitos individuais de $2^{a}$ geração, surgidos no Estado Social, instituem um conjunto de obrigações que devem ser atendidas pelo poder público para satisfazer os direitos individuais. A relação Estado-indivíduo passa a ser uma relação de direito e dever, passa a ser uma relação jurídica e, com isso, o Poder Judiciário torna-se o principal controlador do Estado.

Jean Carbonier ${ }^{7}$ comenta a transição do modelo político de Estado Liberal para o Estado Social, separando numa trilogia:

1. Liberdades: instituem a prerrogativa individual de resistir a abusos cometidos pelo Estado. Referem os direitos individuais ou de $1^{\mathrm{a}}$ geração;

2. Direitos: dependem da atuação da estrutura do Estado para serem satisfeitos. Correspondem aos direitos sociais ou de $2^{\mathrm{a}}$ geração;

3. Garantias: são instrumentos de efetivação de liberdades e direitos. Transgredidas as liberdades ou não atendidos os direitos entram em ação as garantias. Por exemplo, desrespeitada a liberdade de locomoção usa-se a garantia do habeas corpus, não atendido um direito individual, maneja-se o mandado de segurança.

Tanto os direitos individuais quanto os sociais encontram-se compreendidos na categoria dos direitos fundamentais, pois estes configuram uma categoria elástica, de dimensões variáveis, sempre abrangente dos direitos que se encontram na base de um certo modelo de Estado. São

${ }^{7}$ CARBONIER, Jean. Sociologia jurídica. Coimbra: Almedina, 1979.

Revista de Direito Brasileira | São Paulo, SP | v. 18 | n. 7 | p. 363 - 373 |Set./Dez. 2017 
fundamentais os direitos de $1^{a}$ geração porque determinam o modelo de Estado Liberal. Também o são os direitos sociais porque inauguram o modelo de Estado Social.

A nova marca do estado, como se vem registrando, é a prestação de serviços públicos. Quanto mais e melhores serviços o Estado prestar, mais forte ficará sua base de legitimidade, sendo cada vez menos importante o modo pelo qual o governo é exercido. Para a Escola de Frankfurt o Estado Social aparece como um perigo para a democracia, pois mascara a realidade, na medida em que esconde seu matiz político, fortalece o governante, pois restará abstraído da disputa de forças própria do cenário político. O líder político passa a ser o administrador de uma grande empresa prestadora de serviços.

A prestação de serviços públicos acarreta a valorização da igualdade formal, na medida em que deverão ser prestados a todos da mesma forma, com o mesmo padrão. $\mathrm{O}$ tratamento desigual do usuário do serviço é discriminatório.

No mesmo compasso ganha prevalência o princípio da impessoalidade, pois prestador do serviço público não é o agente público, a pessoa física investida de atribuições do poder público. Quem presta o serviço é o Estado, considerado impessoalmente como instituição. E quem responde por seus atos é o Estado ${ }^{8}$. A impessoalidade é o pressuposto da igualdade formal. O usuário é apenas um número, algo que não o identifica como um status, mas como um simples usuário dos serviços do Estado. Nesse padrão de impessoalidade Weber ancorou o modelo democrático caracterizado pelo acesso de todos aos serviços públicos.

A submissão da relação de prestação de serviço público à disciplina jurídica, além de inaugurar o Direito Administrativo, como já assinalado, aproxima gradativamente, por imantação, o Direito do Governo e, na mesma escala, a consolidação do Direito Constitucional leva à fagocitação do fenômeno político pela disciplina jurídica.

Assim, por intermédio das referidas influências históricas, econômicas e sociais, a disciplina jurídica ganha um espaço cada vez maior, invadindo a seara política que, de início, lhe era alheia. Daí afirmar-se que a partir da Revolução Russa, há um século, foram traçados novos rumos à sociedade e ao direito, mudando sobremaneira a compreensão do papel do Estado.

\section{CONCLUSÃO}

O movimento revolucionário na Rússia, culminado com o estabelecimento da União das Repúblicas Socialistas Soviéticas (URSS), o primeiro país socialista do mundo, instaurou um novo modus vivendi, a "ditadura do proletariado", surgindo, assim, a fase socialista, em razão do crescente proletariado, da fome e insatisfação popular, além das dificuldades econômicas e políticas que provocaram a insurreição contra o regime czarista, sendo relevante observar que o Exército negou-se a marchar contra o povo.

A força dos fatos históricos e disputas por poder e de classes acaba por levar a mudanças no governo, que passa de liberal a socialista moderado, chegando-se à mudança do sistema político e econômico, concedendo aos camponeses o direito exclusivo de exploração das terras. Transferem o controle das fábricas aos operários, expropriam as indústrias e nacionalizam os bancos. Aos poucos, o governo passou a adotar medidas para reduzir a fome e modernizar o país.

A formação da URSS, em 1922, tentou manter unidos diversos territórios do antigo Império Russo que pouco têm em comum. No entanto, a decadência do Império socialista russo já começou a dar mostras na década de 1970, identificada pela grave crise em seu sistema político, devido ao crescimento dos movimentos nacionalistas, e pela dificuldade econômica.

\footnotetext{
${ }^{8}$ Art. 37 da Constituição Federal: “A administração pública direta e indireta de qualquer dos poderes da União, dos Estados, do Distrito Federal e dos Municípios obedecerá aos princípios da legalidade, impessoalidade, moralidade, publicidade, e eficiência..."
} 
Cabe ressaltar que, conforme destacado nas influências estudadas, o Estado social não teve origem apenas em concepções ideológicas, mas derivou em muito maior grau de contingências econômicas, devido à revolução que se operou nos meios de produção.

A consolidação do modelo de estado de bem-estar social, prestador de serviços públicos, analisada sinteticamente no texto principal, provocou o deslocamento da legitimidade estatal, localizada pelo modelo liberal na participação política dos cidadãos, principalmente pela via do Poder Legislativo, para a prestação de serviços públicos. Mais legítimo é o Estado que presta mais e melhores serviços públicos. Trata-se de um novo modelo de Estado e da fixação de novos direitos.

No entanto, na relação travada pelo indivíduo com o poder público no modelo de Estado social, há falha quando este abusa, excedendo-se na proporção do que é necessário ao atendimento do interesse público, mas também quando se omite, deixando de cumprir o dever de adequadamente prestar o serviço público.

\section{REFERÊNCIA BIBLIOGRAFIA}

CARBONIER, Jean. Sociologia jurídica. Coimbra: Almedina, 1979.

CRUZ, André Luiz Vinhas. A legitimidade do poder de reforma constitucional. Publicada em Juris Síntese no 50 - NOV/DEZ de 2004.

FAORO, Raymundo. Os donos do poder. Ed. Folha de São Paulo, 2000.

HESPANHA, António Manuel. A história do direito na história social. Lisboa: Horizonte Ltda., 1978.

HESPANHA, António Manuel. A cultura jurídica europeia: Síntese de um milênio. Coimbra: Edições Almedina S.A. 2012.

KUNTZ, Rolf. Locke, Liberdade, Igualdade e Propriedade in Clássicos do Pensamento Político. EDUSP: São Paulo, 2004.

LEAL, Victor Nunes. Coronelismo, enxada e voto. $3^{\text {a }}$ ed. $1^{\text {a }}$ reimpressão. Nova Fronteira, 1997.

MOREIRA, Vital. Compreender os direitos humanos. Manual de educação para os direitos humanos. Coimbra Editora. $1^{\text {a }}$ edição. Coimbra. 2014.

MOREIRA, Vital. A mão visível-Mercado e Regulação. Almedina, Coimbra. 2003.

MORRISON, Wayne. Filosofia do Direito. Dos gregos ao pós-modernismo. Martins Fontes, São Paulo, $1^{\text {a }}$. ed., 2006. 